\title{
THE CHEMISTRY OF THE FISKENASSET COMPLEX ON QEQERTARSSUATSIAQ
}

\author{
Brian F. Windley
}

Rock and mineral analyses arranged in stratigraphic order through the Fiskenæsset complex provide a basis for discussing its geochemistry, a summary of which is given here. Eighteen XRF whole rock analyses made at Leeds University have been used by Windley, Herd \& Bowden (in press) to determine the way-up of the intrusion and to provide preliminary bulk geochemical trends. One hundred and twenty eight mineral analyses made with the ARL electron probe at Chicago University by Windley \& Smith (in press) have been used to determine cryptic variation trends in the intrusion and to establish distribution patterns of elements within major phases and between coexisting phases.

The complex on the island of Qeqertarssuatsiaq is divisible into nine zones which occupy fairly constant stratigraphic positions both across and along the strike.

\begin{tabular}{|c|c|c|c|}
\hline & tres) & & Zones \\
\hline \multirow[t]{9}{*}{ op } & 50 & 9 & Pyroxene amphibolite \\
\hline & 75 & 8 & Garnet anorthosite \\
\hline & 20 & 7 & Major chromitite \\
\hline & 130 & 6 & Anorthosite \\
\hline & 250 & 5 & $\begin{array}{l}\text { Homogeneous leuco-gabbro with marked cumulus } \\
\text { texture }\end{array}$ \\
\hline & 60 & 4 & Dark gabbro \\
\hline & 5 & & (minor) Chromite-bearing gabbros and pyroxenites \\
\hline & 100 & 3 & Lower layered zone (mostly leuco-gabbros) \\
\hline & 100 & 2 & $\begin{array}{l}\text { Magnetite-rich layered ultramafics (dunites, perido- } \\
\text { tites and pyroxenites) }\end{array}$ \\
\hline Sottom & 200 & 1 & Pyroxene amphibolite \\
\hline
\end{tabular}

In some places this stratigraphy is repeated symmetrically in an isoclinal syncline, whilst in other areas the complex occurs as a single unrepeated unit. Zones 2 to 8 


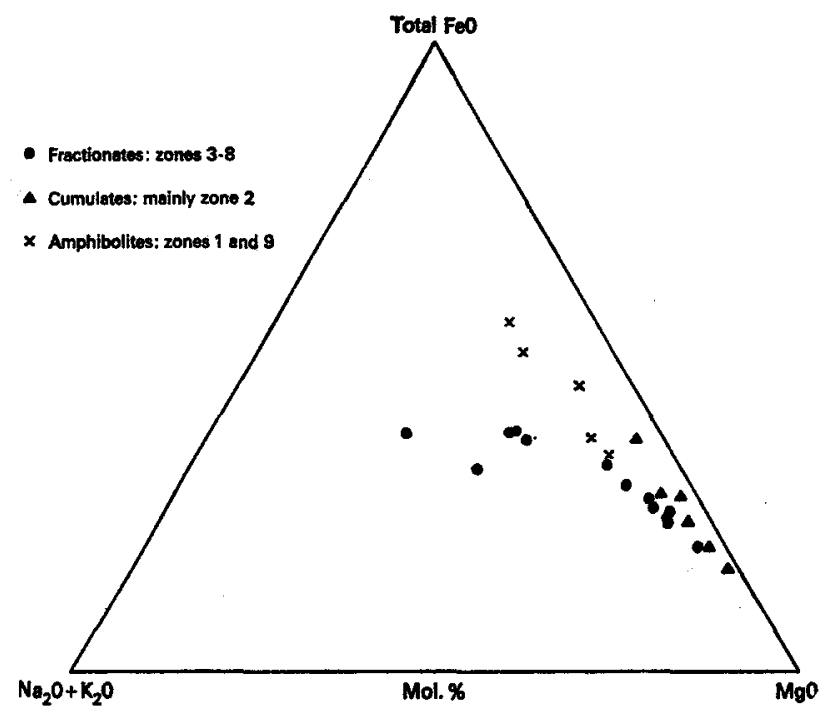

Fig. 7 AFM diagram plotted as mol. \% of oxides for rocks from the Fiskenæsset complex (after Herd, 1972). The cumulates (mainly zone 2) diverge in trend from the fractionates (zones 3-8) due to increase in the latter of alkalis upwards. Some amphibolites of zones 1 and 9 are more iron rich than rocks from the 'intrusion'. (modified after Windley et. al. in press).

belong to the Fiskenæsset 'intrusion' which formed by gravity differentiation after emplacement within basic volcanic rocks subsequently metamorphosed to amphibolites which make up zones 1 and 9 . The complex has been variably recrystallised in hornblende granulite facies and variably retrogressed in amphibolite facies, and it has been folded at least three times. The geochemical studies show that in spite of subsequent metamorphism and deformation much of the original igneous differentiation history of the intrusion is intact.

All samples were collected from a traverse across the complex on south central Qeqertarssuatsiaq in a major fold core chosen because of the great thickness of the complex there (about $1 \mathrm{~km}$ ) and because of its high metamorphic grade; both the complex and the surrounding gneisses show relic granulite facies mineralogy.

Bulk analyses plotted on AFM diagrams define a linear course of crystallisation and demonstrate that the differentiation of one 'half' of the complex mirrors that of the other 'half' confirming the duplicated stratigraphy. Fig. 7 shows that the cumulates (largely of zone 2) diverge in trend from the fractionates of zones 3 to 8 which progressively increase in alkalis upwards. The bulk analyses also show that the $\mathrm{Fe}$ ratio, the total normative feldspar content, and alkalis and alumina increase upwards in the intrusion, whilst $\mathrm{Fe}+\mathrm{Mg}+\mathrm{Mn}$ and Co decrease 


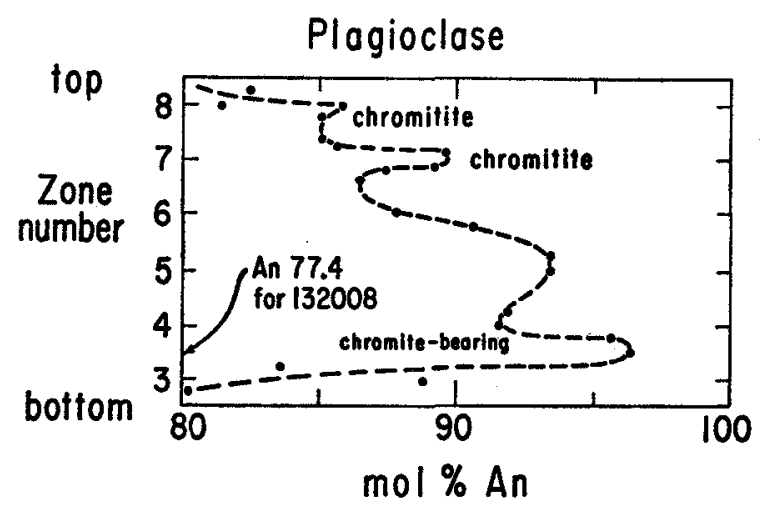

Fig. 8 The variation of anorthite content of plagioclase as a function of zonal positions in the intrusion. Sample 132008 had a lower anorthite content than the remainder. Dashed line drawn by eye (after Windley $\&$ Smith, in press).

accordingly. In all cases the amphibolites of zones 1 and 9 have markedly different compositions from the rocks of the intrusion. By bulking analyses according to the size of the zones the average composition is near that of zone 5 which suggests that the magma had the composition of a hydrous high alumina basalt.

Electron probe analyses of minerals from zones 2 to 8 indicate that cryptic fractionation trends are preserved in several phases. For example, plagioclase changes upwards from $A n_{80}$ to $\mathrm{An}_{86}$ (zone 3) and then decreases to $A n_{80}$ in zone 8 with marked peaks in chromiferous horizons. The $\mathrm{MgO} / \mathrm{FeO}$ ratios of orthopyroxene and olivine in ultramafic rocks lie on smooth curves increasing slightly upwards from zones 2 to 8 . The same ratio in amphibole in anorthosites and gabbros increases twofold from zones 3 to 5 and then decreases fourfold to zone 8. Magnetite displays smooth increases in $\mathrm{Cr}, \mathrm{Ti}, \mathrm{Al}$ and $\mathrm{Mg}$ contents upwards through zones 2 and 3 .

The composition of plagioclase, ortho- and clinopyroxene, olivine and amphibole can be seen in figs 8-10. The amphibole (fig. 10) varies in composition from magnesio-hornblende through tschermakitic hornblende to tschermakite depending on its position in zones 2 to 8 . Garnet in zone 8 is similar to that of Frisch (1971) and chromite in zone 7 is similar to that of Ghisler \& Windley (1967).

There is a positive correlation between the distribution of elements in the following minerals:

amphibole: tetrahedral $\mathrm{Al}$ and $\mathrm{Na}+\mathrm{K}$,

$\mathrm{Na}+\mathrm{K}+\mathrm{Al}$ and $\mathrm{Mg} / \mathrm{Mg}+\mathrm{Fe}+\mathrm{Mn}$,

$\mathrm{MnO}$ and $\mathrm{FeO}$,

$\mathrm{TiO}_{2}$ and $\mathrm{FeO}$,

$\mathrm{Ti}$ and $\mathrm{Na}+\mathrm{K}$ 


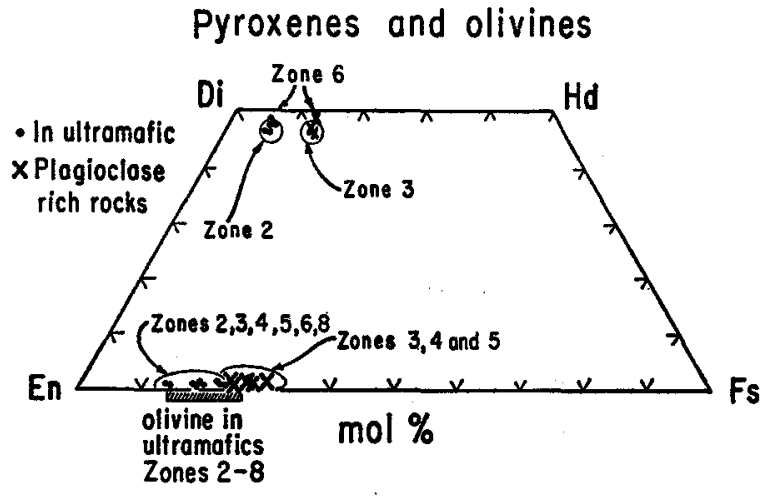

Fig. 9 Olivine-two pyroxene composition diagram plotted on the Di-En-Fs-Hd quadrilateral. (after Windley \& Smith, in press).

olivine: $\quad$ mol. $\% \mathrm{Fe}$ and $\mathrm{Mn}$ and $\mathrm{Ni}$

magnetite: $\quad \mathrm{Cr}$ and $\mathrm{Al}, \mathrm{Mg}, \mathrm{Ti}, \mathrm{Si}, \mathrm{Mn}, \mathrm{Ni}, \mathrm{Ca}$

There is a similar close correlation between the distribution of elements between the following coexisting minerals:

$\mathrm{Mg} / \mathrm{Mg}+\mathrm{Fe}+\mathrm{Mn}$ in amphibole and $\mathrm{Mg}$ in olivine, ortho- and clinopyroxene and phlogopite

$\mathrm{Ca}$ in amphibole and $\mathrm{Ni}$ and $\mathrm{Ca}$ in olivine

$\mathrm{Ni}$ and $\mathrm{Ca}$ in orthopyroxene and in olivine

$\mathrm{Ca}$ in amphibole and in orthopyroxene

$\mathrm{Mn}$ in amphibole and in clinopyroxene

$\mathrm{K} / \mathrm{K}+\mathrm{Na}+\mathrm{Ca}$ in phlogopite and $\mathrm{K}$ in amphibole

$\mathrm{mol} . \% \mathrm{An}$ in plagioclase and $\mathrm{Al}$ in amphibole

mol. $\% \mathrm{Ab}$ in plagioclase and $\mathrm{Na} / \mathrm{Na}+\mathrm{Ca}+\mathrm{K}$ and $\mathrm{K} / \mathrm{Na}+\mathrm{Ca}+\mathrm{K}$ in amphibole

$\mathrm{Mg}, \mathrm{Al}$ and $\mathrm{Cr}$ in amphibole and in chromite

$\mathrm{Cr}$ in hornblende and spinel.

These results show that major and minor elements are regularly distributed between coexisting mineral pairs in the intrusion irrespective of zonal position. This means that elements in different parts of the intrusion have similar distribution coefficients between similar mineral pairs which would be expected in a single metamorphosed igneous body. Herd (1972) has used Pearce's (1968) aluminaratio variation diagrams to show that the differentiation of the intrusion was governed by fractionation of diopside, hypersthene, hornblende, and spinellid phases. Fractionate and cumulate rocks can be distinguished. The dual meta- 


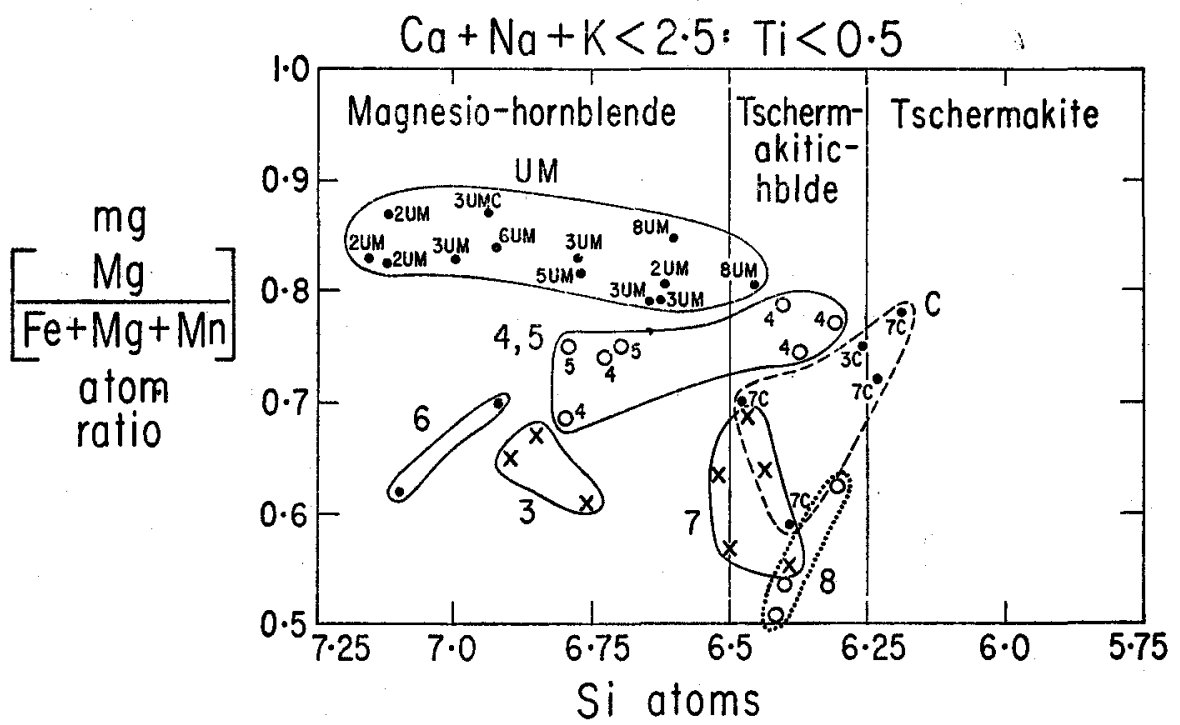

Fig. 10 Amphibole composition diagram based on the classification of Leake (1968). Numbers refer to zones and letters UM to ultramafic and $C$ to chromite-bearing amphibolites. Samples are ringed according to their zonal position or host rock composition (i.e. UM and $7 C+3 C$ ), (after Windley \& Smith, in press).

morphic/igneous nature of the intrusion is illustrated by ACF plots of the wholerock analyses.

The geochemical data is consistent with the crystallisation of a hydrous magma which gave rise to primary amphibole, the cryptic variation trend of which is preserved in the metamorphic derivatives. The main reason why the plagioclase is very calcic is because the formation of amphibole removed less calcium and more sodium from the magma than would clinopyroxene in a dry magma; and a high water pressure would itself increase the An content of the plagioclase. The crystallising hydrous magma followed a non-iron enrichment differentiation trend (fig. 7), illustrated by the fact that amphibole was consistently magnesian. The formation of early magnetite in zone 2 and late chromite in zone 7 is consistent with the high oxidation state of such a magma. A high water pressure in the original magma explains many mineralogical and chemical features of the Fiskenæsset intrusion.

In spite of subsequent metamorphism some relic igneous primocrysts are preserved in certain layers; in particular plagioclase in zone 5 gabbros, and olivine, pyroxenes and amphibole in zone 2 ultramafics. These are surrounded by a finer grained matrix where it can be seen that they are in the process of breakdown by recrystallisation to metamorphic granules. One of the conclusions drawn from this study is that granulite facies metamorphism can be sufficiently isochemical 
to allow so little element diffusion that igneous mineral characteristics can be preserved in the metamorphic state.

\section{References}

Frisch, T. 1971: Chemical data on some rock-forming minerals from high-grade gneisses, amphibolites, and anorthosites from the Fiskenæesset area. Rapp. Grønlands geol. Unders. 35, 22-23.

Ghisler, M. \& Windley, B. F. 1967: The chromite deposits of the Fiskenæsset region, West Greenland. Rapp. Grønlands geol. Unders. 12, $39 \mathrm{pp}$.

Herd, R. K. 1972: The petrology of the sapphirine-bearing and associated rocks of the Fiskenæsset complex, West Greenland. Unpubl. PhD thesis, Univ. of London.

Leake, B. E. 1968: A catalog of analysed calciferous and subcalciferous amphiboles together with their nomenclature and associated minerals. Spec. Pap. geol. Soc. Amer. 98, 210 pp.

Pearce, T. H. 1968: A contrbution to the theory of variation diagrams. Contr. Miner. Petrol. 19, 142-157.

Windley, B. F. \& Smith, J. V. in press: The Fiskenæsset complex, West Greenland. Part II: General mineral chemistry. Bull. Grønlands geol. Unders. (also Meddr Grønland).

Windley, B. F., Herd, R. K. \& Bowden, A. A. in press: The Fiskenæesset complex, West Greenland. Part I: A preliminary study of the stratigraphy, petrology and whole-rock chemistry. Bull. Grønlands geol. Unders. (also Meddr Grønland 196, 2). 